\title{
Prevalence of white spot syndrome virus (WSSV) in wild shrimp Penaeus monodon in the Philippines
}

\author{
Leobert D. de la Peña*, Celia R. Lavilla-Pitogo, Corina Belle R. Villar, \\ Milagros G. Paner, Christopher D. Sombito, Geimbo C. Capulos
}

Southeast Asian Fisheries Development Center, Aquaculture Department, Tigbauan 5021, Iloilo, Philippines

\begin{abstract}
Prevalence of white spot syndrome virus (WSSV) was determined using polymerase chain reaction (PCR) methodology on DNA extracted from the gills of wild black tiger shrimp Penaeus monodon collected from 7 sampling sites in the Philippines. These 7 sampling sites are the primary sources of spawners and broodstock for hatchery use. During the dry season, WSSV was detected in shrimp from all sites except Bohol, but during the wet season it was not detected in any site except Palawan. None of the WSSV-PCR positive shrimp showed signs of white spots in the cuticle. Prevalence of WSSV showed seasonal variations, i.e. prevalence in dry season (April to May) was higher than in the wet season (August to October). These results suggest that WSSV has already become established in the local marine environment and in wild populations of $P$. monodon. Thus, broodstock collected during the dry season could serve as the main source of WSSV contamination in shrimp farms due to vertical transmission of the virus in hatcheries.
\end{abstract}

KEY WORDS: Disease prevalence $\cdot \mathrm{WSSV} \cdot$ Wild Penaeus monodon $\cdot \mathrm{PCR}$ - Resale or republication not permitted without written consent of the publisher

\section{INTRODUCTION}

Diseases have emerged as the major limiting factor to the sustainable growth of the shrimp culture industry in the Philippines and in the Asia-Pacific region. Most of these diseases are associated with infectious agents such as viruses. At present, there are nearly 20 viral pathogens that can cause serious epizootics in penaeid shrimp (Lightner \& Redman 1998).

White spot disease (WSD) was first described from Japan where an initial outbreak occurred in Penaeus japonicus in 1993 (Nakano et al. 1994), and was thought to have originated from stocks imported from China. WSD is caused by white spot syndrome virus (WSSV), a dsDNA rod-shaped virus with large virions $(70-150 \mathrm{~nm} \times 250-380 \mathrm{~nm})$ that has been classified in the genus Whispovirus of the family Nimaviridae (Vlak et al. 2004). The virus was named after the gross signs of WSD that include high and rapid mortality (reaching up to $100 \%$ within $10 \mathrm{~d}$ of onset of clinical signs) accompanied by white inclusions of various sizes embedded in shrimp cuticle. These white inclusions apparently represent abnormal deposits of calcium salts (Lightner 1996).
All cultivated shrimp species examined are susceptible to WSSV infection. The host range extends widely into other marine and freshwater crustacean species and perhaps to copepods and aquatic insect larvae (Lo et al. 1996). Several species of crabs and shrimp may be infected without displaying gross signs of disease, and they may act as a reservoir for infection of farmed shrimp. Persistence of WSSV in wild crustacean species in the vicinity of shrimp farms may make the disease difficult, if not impossible, to eradicate from affected aquaculture areas.

WSSV is considered the most serious viral pathogen of cultured penaeid shrimp and is now widespread in Asia and the Americas. Although Albaladejo et al. (1998) reported the absence of WSSV from cultured or wild Penaeus monodon in the Philippines in the late 1990s, the disease was found subsequently (Magbanua et al. 2000, de la Peña et al. 2003). The establishment of specific pathogen free (SPF) domesticated shrimp stocks ranks high among possible solutions to the devastating viral diseases in shrimp culture systems. Among the requirements for developing such broodstock is a source of wild shrimps that is genetically diverse and free of the major pathogens currently 
known. As a preliminary step in this direction, we report on the prevalence of WSSV in wild shrimp populations in the Philippines.

\section{MATERIALS AND METHODS}

Preliminary sampling. Preliminary sampling was conducted at each site to determine in detail the location of wild shrimp sources, contact persons, approximate number of shrimp samples that could be collected per day, prices, place to process and stay, and modes of transportation. At each sampling site, a shrimp collector was designated to gather the samples until the desired sample size was reached.

Sample collection and processing. Dry (April to May) and wet (August to October) season samples were collected at 7 sites (Fig. 1): at Quezon and Palawan for the Luzon area, at Capiz, Negros Occidental and Bohol for the Visayan islands, and at Surigao del Sur and Misamis Occidental for Mindanao. Shrimp collection was done by means of trawling between 7 and 30 fathoms ( 1 fathom $=1.83 \mathrm{~m}$ ) except for Palawan where an improvised lighting and a scoop net were used, and for Surigao del Sur where trap nets were used to capture the shrimp in mangrove areas. Trawling activities in Puerto Princesa Bay, Palawan are banned by the local government unit.

At least 100 shrimp samples were gathered per site for the dry and wet seasons. Shrimp samples from Bohol, Quezon, Palawan and Misamis Occidental were transported in fry bags supplied with aerated seawater for an average of $10 \mathrm{~min}$ from the collector's holding facility to the working area for individual processing. Samples from Capiz, Negros Occidental and Surigao del Sur were processed directly in the collector's holding facility. Gill tissues of each shrimp were dissected aseptically, fixed in $95 \%$ ethanol, stored at $4^{\circ} \mathrm{C}$ and individually processed for PCR analyses.

DNA extraction. DNAzol reagent (Invitrogen) was used for extraction of DNA according to the manufacturer's instructions. Briefly, approximately $50 \mathrm{mg}$ of gill tissue were homogenized in $1 \mathrm{ml}$ DNAzol, followed by centrifugation for $10 \mathrm{~min}$ at $14800 \times \mathrm{g}$ at $4^{\circ} \mathrm{C}$ and transfer of the supernatant to a new tube. DNA was precipitated by the addition of $0.5 \mathrm{ml}$ of $100 \%$ ethanol. Pelleted DNA was washed twice with $95 \%$ ethanol by centrifugation and air-dried for a few seconds. The dried DNA pellets were suspended in $100 \mu \mathrm{l}$ of $8 \mathrm{mM}$ $\mathrm{NaOH}$, incubated at $45^{\circ} \mathrm{C}$ for $15 \mathrm{~min}$, after which $10 \mu \mathrm{l}$ of TE buffer was added for storage at $-20^{\circ} \mathrm{C}$.

Detection of WSSV using PCR. The DNA samples were submitted to 1-step and nested PCR tests using the WSSV-specific primer pairs designed by Kimura et al. (1996). PCR reactions were carried out in a $25 \mu \mathrm{l}$

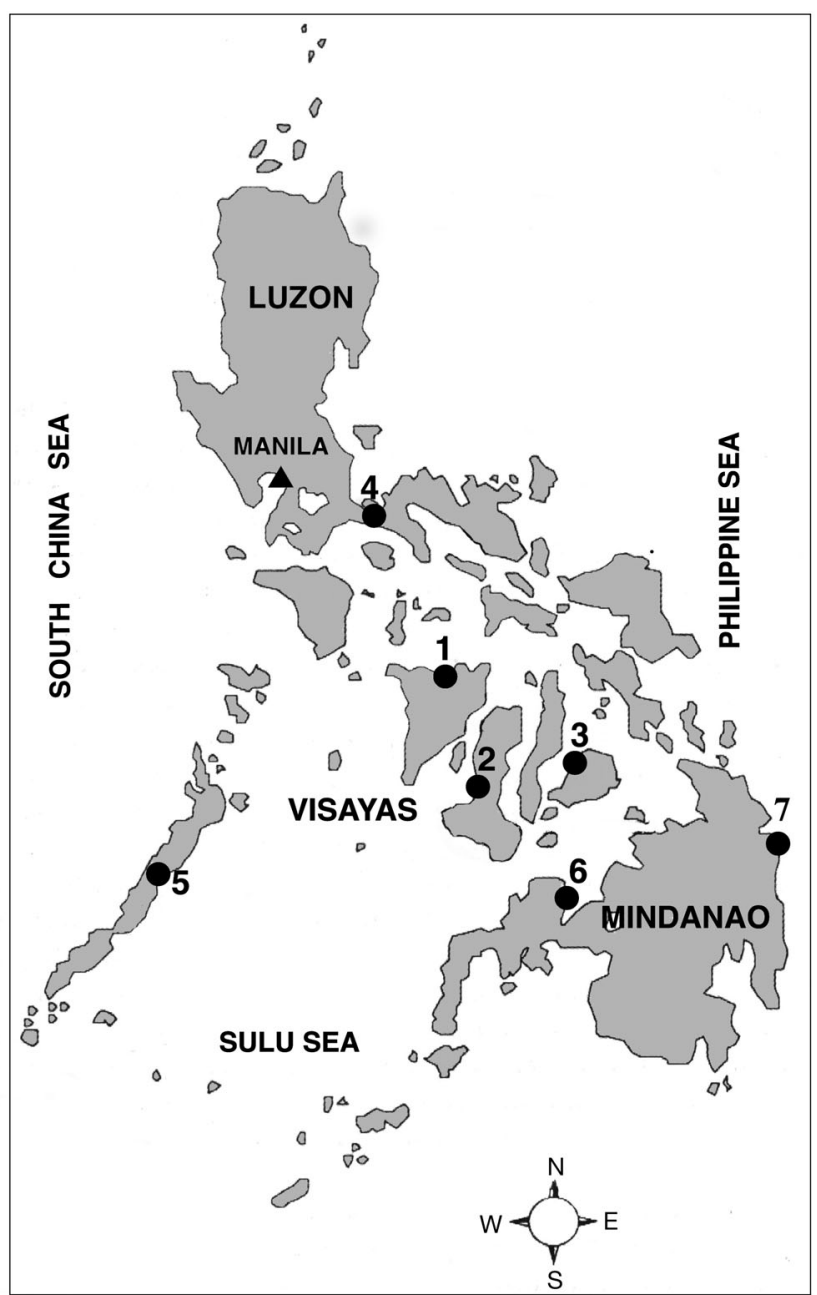

Fig. 1. Map of the Philippines showing the 7 sampling sites. 1: Capiz $\left(11^{\circ} 03^{\prime} \mathrm{N}, 122^{\circ} 45^{\prime} \mathrm{E}\right)$; 2: Negros Occidental $\left(10^{\circ} 05^{\prime} \mathrm{N}, 122^{\circ} 51^{\prime} \mathrm{E}\right) ; 3$ : Bohol (9॰57' N, $\left.123^{\circ} 57^{\prime} \mathrm{E}\right) ; 4$ : Quezon $\left(13^{\circ} 54^{\prime} \mathrm{N}, \quad\left(121^{\circ} 44^{\prime} \mathrm{E}\right) ; \quad 5:\right.$ Palawan $\left(9^{\circ} 44^{\prime} \mathrm{N}, 1^{\circ} 18^{\circ} 43^{\prime} \mathrm{E}\right)$; 6: Misamis Occidental $\left(8^{\circ} 08^{\prime} \mathrm{N}, 123^{\circ} 50^{\prime} \mathrm{E}\right) ; 7$ : Surigao del Sur $\left(8^{\circ} 22^{\prime} \mathrm{N}, 126^{\circ} 19^{\prime} \mathrm{E}\right)$

reaction mixture. Amplification was performed in a programmable thermal cycler (Eppendorf Mastercycler) with the following cycle parameters: the initial heating at $72^{\circ} \mathrm{C}$ for $10 \mathrm{~min}$ and $95^{\circ} \mathrm{C}$ for $6 \mathrm{~min}$, followed by 30 cycles of denaturation at $95^{\circ} \mathrm{C}$ for $1 \mathrm{~min}$, annealing at $57^{\circ} \mathrm{C}$ for $1 \mathrm{~min}$ and extension at $72^{\circ} \mathrm{C}$ for $1 \mathrm{~min}$ with a final extension at $72^{\circ} \mathrm{C}$ for 5 min before holding at $4^{\circ} \mathrm{C}$ until ready for electrophoresis.

For the nested PCR step, $1.0 \mu \mathrm{l}$ of the post-1-step PCR mixture (using primer pair P1-P2) was used as the template for PCR amplification (using the primer pair P3-P4) with the protocol described above. The products were separated in $1.5 \%$ agarose gels, stained with ethidium bromide and visualized using a Gel Documentation System (Syngene, GeneGenius). The outer and inner primer pairs amplified products of 982 and $570 \mathrm{bp}$, respectively. 
Table 1. Penaeus monodon. Data for wild specimens collected during the dry and wet season samplings from 7 sites. The wet season value is given in parentheses after the dry season value. ABW: average body weight (g)

\begin{tabular}{|c|c|c|c|c|c|c|c|}
\hline \multirow{3}{*}{ Shrimp parameter } & \multirow{2}{*}{\multicolumn{2}{|c|}{ Luzon $\longrightarrow$}} & \multirow{2}{*}{\multicolumn{3}{|c|}{$\begin{array}{l}\text { Sampling site } \\
\end{array}$}} & \multirow{2}{*}{\multicolumn{2}{|c|}{ L Mindanao }} \\
\hline & & & & & & & \\
\hline & Quezon & Palawan & Capiz & Negros & Bohol & Misamis & Surigao \\
\hline Total no. of shrimp & $103(106)$ & $102(103)$ & $100(103)$ & $101(101)$ & $102(100)$ & $100(100)$ & 105 (101) \\
\hline ABW overall & $92(123)$ & $55(74)$ & $106(137)$ & 59 (135) & $96(111)$ & $112(129)$ & 90 (103) \\
\hline Number of females & $63(83)$ & $58(64)$ & $50(72)$ & $51(85)$ & $54(71)$ & $81(92)$ & $91(72)$ \\
\hline ABW females & 109 (136) & $61(82)$ & $132(157)$ & $64(142)$ & $117(123)$ & $119(134)$ & 93 (119) \\
\hline Ovarian stage & & & & & & & \\
\hline 0 & 33 (35) & $55(56)$ & $30(12)$ & $37(14)$ & $31(31)$ & $37(24)$ & $74(18)$ \\
\hline 1 & $27(25)$ & $2(7)$ & $17(40)$ & $11(34)$ & $16(26)$ & 39 (41) & $16(34)$ \\
\hline 2 & 3 (13) & $1(1)$ & $3(15)$ & $1(21)$ & $5(10)$ & $5(22)$ & $1(14)$ \\
\hline 3 & $0(7)$ & $0(0)$ & $1(5)$ & 0 (12) & $1(4)$ & $0(4)$ & $0(5)$ \\
\hline 4 & $0(3)$ & $0(0)$ & $0(0)$ & $1(4)$ & $1(0)$ & $0(0)$ & $0(1)$ \\
\hline Number of males & $40(23)$ & 44 (39) & $50(31)$ & $50(16)$ & $48(29)$ & $19(8)$ & $14(29)$ \\
\hline ABW males & $62(77)$ & $47(61)$ & $78(90)$ & $52(96)$ & $73(80)$ & $80(76)$ & $62(64)$ \\
\hline
\end{tabular}

Statistical analysis. Mean prevalence between regions (Luzon, Visayas and Mindanao) for both wet and dry seasons was compared using 1-way ANOVA following the Sigmastat software. A $t$-test was used to compare the mean prevalence between male and female, and between small and large size categories following the statistical program for the social sciences. (SPPS ver. 10.0)

\section{RESULTS}

Table 1 gives details of the wild Penaeus monodon samples gathered during the dry and wet seasons, including differences in average body weights (ABW) of males and females and stages in ovarian development for females at each sampling site. Most of the females collected were at either stage 0 or 1 . Shrimp were classified into small and large categories based on the median measurements in their weights. Weights of the shrimp were dependent on the depth and method of capture. Shrimp captured by trawling were usually the heaviest.

The mean weights of shrimps were 87 and $116 \mathrm{~g}$ in the dry and wet seasons, respectively. The mean weight of shrimp in the dry season was significantly smaller than that in the wet season $(p<0.05)$.

WSSV detection by PCR (Table 2) for the dry season showed that all shrimp samples were negative after 1-step PCR, but after nested PCR some were positive (3 to $25 \%$ ) (Table 2 ) from every site, except for Bohol. The mean $( \pm \mathrm{SD})$ prevalence for WSSV-positive broodstock for all sites was $9.6 \pm 8.8 \%$. Removing Bohol, the mean prevalence was $11.2 \pm 8.4 \%$. Focusing on regions, the mean prevalence for the Visayan region $(2 \pm 1.7 \%)$ was significantly lower $(p<0.05)$ than that for the Luzon region $(10 \pm 1.4 \%)$ and the Mindanao region
$(20.5 \pm 6.4 \%)$. Although the mean for the Mindanao region was higher than that for the Luzon region, the difference was not statistically significant ( $p>0.05)$. On the other hand, there were only 2 sample sites for each of the Luzon and Mindanao areas, and it is possible that the sampling of a larger number of sites would have indicated a significant difference between the 2 regions.

For all shrimp samples collected in the wet season (Table 2), 1-step PCR WSSV test results were negative, and only one site (Palawan from the Luzon region) gave $2 \%$ WSSV positive test results $(2 / 103)$ by nested PCR. The overall mean prevalence for all sites was $0.3 \pm$ $0.8 \%$, and this was significantly different from the overall mean $(9.6 \pm 8.8 \%)$ for the dry season $(p<0.02)$.

Mean prevalence of WSSV was high in both sexes in the dry season (12\% and $6 \%$, respectively) and low for both sexes in the wet season $(0.4 \%$ and $0 \%$, respec-

Table 2. Penaeus monodon. WSSV detection using PCR on wild samples during dry and wet seasons

\begin{tabular}{|lcl|}
\hline Sampling site & Dry season & Wet season \\
\hline Luzon & & \\
$\quad$ Quezon & $9 / 103(9 \%)$ & $0 / 106(0 \%)$ \\
Palawan & $11 / 102(11 \%)$ & $2 / 103(2 \%)$ \\
$\quad$ Sub-total & $20 / 205(10 \%)$ & $2 / 209(1 \%)$ \\
Visayas & & \\
Capiz & $3 / 100(3 \%)$ & $0 / 103(0 \%)$ \\
$\quad$ Negros Occidental & $3 / 101(3 \%)$ & $0 / 101(0 \%)$ \\
Bohol & $0 / 102(0 \%)$ & $0 / 100(0 \%)$ \\
$\quad$ Sub-total & $6 / 303(2 \%)$ & $0 / 304(0 \%)$ \\
Mindanao & & \\
Misamis Occidental & $16 / 100(16 \%)$ & $0 / 100(0 \%)$ \\
Surigao del Sur & $26 / 105(25 \%)$ & $0 / 101(0 \%)$ \\
$\quad$ Sub-total & $42 / 205(20 \%)$ & $0 / 201(0 \%)$ \\
Grand total & $68 / 713(10 \%)$ & $2 / 714(0.3 \%)$ \\
\hline
\end{tabular}


Table 3. Penaeus monodon. Prevalence of WSSV in male and female wild samples in the Philippines

\begin{tabular}{|c|c|c|c|c|}
\hline \multirow{2}{*}{ Sampling site } & \multicolumn{2}{|c|}{ Dry season -} & \multicolumn{2}{|c|}{ Wet season } \\
\hline & Male & Female & Male & Female \\
\hline \multicolumn{5}{|l|}{ Luzon } \\
\hline Quezon & $3 / 40(8 \%)$ & $6 / 63(10 \%)$ & $0 / 23(0 \%)$ & $0 / 83(0 \%)$ \\
\hline Palawan & $4 / 44(9 \%)$ & $7 / 58(12 \%)$ & $0 / 39(0 \%)$ & $2 / 64(3 \%)$ \\
\hline \multicolumn{5}{|l|}{ Visayas } \\
\hline Capiz & $3 / 50(6 \%)$ & $0 / 50(0 \%)$ & $0 / 31(0 \%)$ & $0 / 72(0 \%)$ \\
\hline Negros Occidental & $1 / 50(2 \%)$ & $2 / 51(4 \%)$ & $0 / 16(0 \%)$ & $0 / 85(0 \%)$ \\
\hline Bohol & $0 / 48(0 \%)$ & $0 / 54(0 \%)$ & $0 / 29(0 \%)$ & $0 / 71(0 \%)$ \\
\hline \multicolumn{5}{|l|}{ Mindanao } \\
\hline Misamis Occidental & l 2/19 (11\%) & $14 / 81(17 \%)$ & $0 / 8(0 \%)$ & $0 / 92(0 \%)$ \\
\hline Surigao del Sur & $2 / 14(14 \%)$ & $24 / 91(26 \%)$ & $0 / 29(0 \%)$ & $0 / 72(0 \%)$ \\
\hline Total & $15 / 265(6 \%)$ & $53 / 448(12 \%)$ & $0 / 175(0 \%)$ & $2 / 539(0.4 \%)$ \\
\hline
\end{tabular}

Table 4. Penaeus monodon. Prevalence of WSSV in small (12-102 g) and large (103-266 g) wild specimens in samples from the Philippines

\begin{tabular}{|c|c|c|c|c|}
\hline \multirow[t]{2}{*}{ Sampling site } & \multicolumn{2}{|c|}{- Dry season -} & \multicolumn{2}{|c|}{ Wet season } \\
\hline & Small & Large & Small & Large \\
\hline \multicolumn{5}{|l|}{ Luzon } \\
\hline Quezon & $6 / 62(10 \%)$ & $3 / 41(7 \%)$ & $0 / 27(0 \%)$ & $0 / 79(0 \%)$ \\
\hline Palawan & $11 / 97(11 \%)$ & $0 / 5(0 \%)$ & $2 / 90(2 \%)$ & $0 / 13(0 \%)$ \\
\hline \multicolumn{5}{|l|}{ Visayas } \\
\hline Capiz & $3 / 48(6 \%)$ & $0 / 52(0 \%)$ & $0 / 26(0 \%)$ & $0 / 77(0 \%)$ \\
\hline Negros Occidental & $2 / 85(2 \%)$ & $1 / 16(6 \%)$ & $0 / 16(0 \%)$ & $0 / 85(0 \%)$ \\
\hline Bohol & $0 / 71(0 \%)$ & $0 / 31(0 \%)$ & $0 / 46(0 \%)$ & $0 / 54(0 \%)$ \\
\hline \multicolumn{5}{|c|}{ Mindanao } \\
\hline Misamis Occidental & al34 (12\%) & $12 / 66(18 \%)$ & $0 / 12(0 \%)$ & $0 / 88(0 \%)$ \\
\hline Surigao del Sur & $22 / 77(29 \%)$ & $4 / 28(14 \%)$ & $0 / 47(0 \%)$ & $0 / 54(0 \%)$ \\
\hline Total & $48 / 474(10 \%)$ & $20 / 239(8 \%)$ & $2 / 264(0.8 \%)$ & $0 / 450(0 \%)$ \\
\hline
\end{tabular}

frequencies of $9 \%$ and $25 \%$, respectively. With the same methodology, Kou et al. (2001) reported the prevalence of WSSV in wild $P$. monodon brooders in Taiwan at $20 \%$. In Thailand, a prevalence of $18 \%$ was recorded during the highest peak from September to November (using 1-step PCR; Withyachumnarnkul et al. 2003).

Although we did not see a clear difference in WSSV prevalence between wild female and male shrimp, there was a significant seasonal variation, with higher prevalence during the dry or summer season. This period of high prevalence coincides with the period of natural spawning activity in the wild. This usually starts in March every year, with brooders spawning repeatedly (J. H. Primavera pers. comm.). This may explain why samples obtained from the following April and May had the highest prevalence of WSSV. Lo et al. (1997) have proven experimentally that stress inherent in spawning triggers increased replication of WSSV (Kou et al. 2001) and can lead to WSD in latently infected brooders, sometimes leading to death after spawning. A lower WSSV prevalence during the wet season might be due to the death of infected broodstock after spawning, although this hypothetively) (Table 3). Although the mean prevalence was higher for the females than males in both seasons, the difference was not statistically significant ( $p>0.05)$. On the other hand, the number of positive shrimp at each site, especially in the wet season, was relatively low and it is possible that a larger sample size would have indicated a significant difference based on sex.

WSSV prevalence was $10 \%$ within the small size category of shrimps and $8 \%$ in the large size category during the dry season (Table 4). During the wet season, prevalence was $0.8 \%$ and $0 \%$ for the small and large size categories, respectively. WSSV prevalence for small and large size categories were not statistically significant in neither dry nor wet seasons ( $p>0.05)$.

\section{DISCUSSION}

This study confirms the presence of WSSV in wild Penaeus monodon in the Philippines. There are few reports that describe the health status of wild penaeid shrimp. Using nested PCR, Mushiake et al. (1998) and Maeda et al. (1998) found WSSV in wild P. japonicus in Japan at sis could not be verified easily in the wild. The occurrence of a seasonal peak in WSSV prevalence during the summer season is concordant with results from Japan (Mushiake et al. 1998) and Taiwan (Lo et al. 1997), but not from Thailand where the peak occurs during the wet season from September to November (Withyachumnarnkul et al. 2003).

Since all of our positive results were obtained only by using nested PCR, the viral loads in our samples were relatively low and corresponded to levels characteristic of the WSSV carrier state (Hsu et al. 1999, Peng et al. 2001). The relatively high prevalence of WSSV in Palawan is interesting, since shrimp aquaculture activities in that area are minimal. On the other hand, cargo ships that carry fouling organisms and discharge ballast water sail between Palawan and countries such as Taiwan, Malaysia and Indonesia, which have documented outbreaks of WSSV. Information we gathered from the Philippine Ports Authority in Puerto Princesa City, Palawan confirmed that foreign ships with ports of origin from Malaysia, Korea and Indonesia travel the route at a frequency of once or twice a month. Thus, it is possible that fouling organisms and/or ballast water 
organisms discharged from cargo ships may contribute to the high prevalence of WSSV in the area.

Another possible source of WSSV-infected shrimp, especially for broodstock captured from shallow inshore waters may be escapees or discards from shrimp farms (Withyachumnarnkul et al. 2003). This may explain the high prevalence of WSSV in the samples from Surigao del Sur (highest prevalence of WSSV) that were captured with trap nets installed at 7 to $8 \mathrm{~m}$ depth. However, there is a low prevalence of WSSV in the Visayas area (Table 2) where there is large scale shrimp cultivation. This observation contradicts our assumption that WSSV-infected shrimp may come from farms.

Although we found that the prevalence of WSSV was higher in smaller shrimp, the test results were not statistically significant, and the shrimp collected during the dry season were smaller than those collected during the wet season. Thus, the difference is more likely to be a seasonal effect rather than a shrimp size effect. In the Philippines, adolescent Penaeus monodon are found in surface waters in estuaries while small spawners are mainly caught in shallow waters (Motoh 1981). Again, this suggests a possible link between WSSV infection status and aquaculture farming effluents discharged into shallow marine waters inhabited by small shrimp.

Based on our results, we believe that WSSV has been established in the local marine environment and in wild populations of Penaeus monodon for some time. Thus, spawners collected especially during the dry season have an increased risk of WSSV infection and are capable of vertically transmitting the virus to post larvae used to stock rearing ponds. This is very important because the only current source of broodstock is from the wild. In the absence of a national domestication program for black tiger shrimp, our results may assist broodstock collectors in reducing the risk of WSSV contamination by avoiding smaller individuals and carefully selecting the collection site.

Acknowledgements. This study was funded by the Government of Japan Trust Fund to SEAFDEC AQD under the study code GOJ-TF 6251-100-60. Thanks are due to Y. Inui, K. Nagasawa and K. Okuzawa (fish disease experts) for their guidance during the study and to $\mathrm{M}$. Peniero, R. Traviña and V. Suarnaba for their technical assistance. We are very grateful to S. Alisasis, D. Aragon, M. Uy, R. Dieta, R. Abrera, R. Seballos and B. Lim, who gave us access to their farms and stations for sampling, and provided wild shrimp samples.

\section{LITERATURE CITED}

Albaladejo JD, Tapay LM, Migo VP, Alfafara CG and 9 others (1998) Screening for shrimp viruses in the Philippines. In: Flegel TW (ed) Advances in shrimp biotechnology. BIOTEC, National Center for Genetic Engineering and Biotechnology, Chiengmai, p 251-253 de la Peña LD, Lavilla-Pitogo CR, Namikoshi A, Nishizawa T, Inui Y, Muroga K (2003) Mortality in pond-cultured shrimp Penaeus monodon in the Philippines associated with Vibrio harveyi and white spot syndrome virus. Fish Pathol 38:59-61

Hsu HC, Lo CF, Lin SC, Liu KF and 5 others (1999) Studies on effective PCR screening strategies for white spot syndrome virus (WSSV) detection in Penaeus monodon brooders. Dis Aquat Org 39:13-19

Kimura T, Yamano K, Nakano H, Momoyama K, Hiraoka M, Inouye K (1996) Detection of penaeid rod-shaped DNA virus (PRDV) by PCR. Fish Pathol 31:93-98

Kou GH, Chang YS, Peng SE, Lo CF (2001) Viral infection of cultured shrimp in Taiwan. In: Proceedings of the JSPSNRCT international symposium on sustainable shrimp culture and health management diseases and environment. Tokyo University of Fisheries, Tokyo, p 15-27

Lightner DV (1996) A handbook of shrimp pathology and diagnostic procedures for disease of cultured penaeid shrimp. World Aquaculture Society, Baton Rouge, LA

Lightner DV, Redman RM (1998) Strategies for the control of viral diseases of shrimp in the Americas. Fish Pathol 33: $165-180$

Lo $\mathrm{CF}_{\text {, Ho } \mathrm{CH}}$, Peng SE, Chen $\mathrm{CH}$ and 7 others (1996) White spot syndrome baculovirus (WSBV) detected in cultured and captured shrimp, crabs and other arthropods. Dis Aquat Org 27:215-225

Lo CF, Ho CH, Chen CH, Liu KF and 9 others (1997) Detection and tissue tropism of white spot syndrome baculovirus (WSBV) in captured brooders of Penaeus monodon with a special emphasis on reproductive organs. Dis Aquat Org 30:53-72

Maeda M, Itami T, Furumoto A, Hennig O and 5 others (1998) Detection of penaeid rod-shaped DNA virus (PRDV) in wild-caught shrimp and other crustaceans. Fish Pathol 33: 373-380

Magbanua FO, Natividad KT, Migo VP, Alfafara CG and 6 others (2000) White spot syndrome virus (WSSV) in cultured Penaeus monodon in the Philippines. Dis Aquat Org 42:77-82

Motoh, H (1981) Studies on fisheries biology of giant tiger prawn, Penaeus monodon in the Philippines. Tech Rep No. 7. Southeast Asian Fisheries Development Center, Tigbauan, Iloilo

Mushiake K, Arimoto M, Satoh J, Mori K (1998) Detection of PRDV from wild adult kuruma prawn. Fish Pathol 33: 503-509

Nakano H, Koube H, Umezawa S, Momoyama K, Hiraoka M, Inouye K, Oseko N (1994) Mass mortalities of cultured kuruma shrimp, Penaeus japonicus in Japan in 1993: epizootiological survey and infection trials. Gyobyo Kenkyu (Fish Pathol) 29:135-139 (in Japanese with English abstract)

Peng SE, Lo CF, Lin SC, Chen LL, Chang YS, Liu KF, Su MS, Kou GH (2001) Performance of WSSV-infected and WSSV-negative Penaeus monodon postlarvae in culture ponds. Dis Aquat Org 46:165-172

Vlak JM, Bonami JR, Flegel TW, Kou GH, Lightner DV, Lo CF, Loh PC, Walker PW (2004) Nimaviridae. In: Fauquet CM, Mayo MA, Maniloff J, Desselberger U, Ball LA (eds) VIIIth report of the International Committee on Taxonomy of Viruses. Elsevier, Amsterdam, p 187-192

Withyachumnarnkul B, Boonsaeng V, Chomsoong R, Flegel TW, Muangsin S, Nash GL (2003) Seasonal variation in white spot syndrome virus-positive samples in broodstock and post-larvae of Penaeus monodon in Thailand. Dis Aquat Org 53:167-171 